\title{
PENGARUH MATERI CERITA TERHADAP PERKEMBANGAN KEPRIBADIAN ANAK
}

\author{
Endin Mujahidin dan Agustini Diah Pancawati \\ (Universitas Ibn Khaldun Bogor) \\ Email: endin.mujahidin@ uika-bogor.ac.id
}

Received: 27-07-2018, Accepted: 13-08-2018, Publish: 03-09-2018

\begin{abstract}
Content of story give an important role for building person's character, especially during childhood. It is importantto select the proper story matterfor generating good character of children. Qur'an contains a lot of noble storiesthat can be used as references for educator, such asstory about human being, universe, animals etc. Properties of story matter in Qur'an always imply the lesson and have accurate historical evidence; therefore the learnersare not taught through lies. Story can be effective if complemented by several factorssuch as covered in interesting tittle, more than once delivery or repeatedly, suitable time (when the child relaxes or alpha wave brain), simple language and usingproper approach. Conversely, several factors that will give uneffectiveimpact of story matter are formal method, inflexible, hollow meaning, pressure, long duration, wrong time (when the child in a beta wave brain), bored language and not allowing of intellectual, social and emotional stage of children. In summary, it is important to couple the story matter and its effectivefactors for achieving the expected goal.
\end{abstract}

Keywords: story material, personality, child development

\begin{abstract}
Abstrak
Materi cerita memiliki peranan penting dalam pembentukan karakter seseorang, terlebih bagi seorang anak. Oleh karena itu, pemilihan materi cerita yang tepat akan membantu perkembangan kepribadian seorang anak. Di dalam Al-Qur'an, terdapat materi cerita yang dapat dijadikan rujukan bagi seorang pendidik. Materi tersebut bervariasi, mulai dari materi mengenai manusia, alam, hewan dan sejenisnya. Karakteristik materi cerita dalam Al-Qur'an senantiasa menyiratkan pelajaran dan memiliki bukti sejarah yang akurat, sehingga anak didik tidak diajar dengan kebohongan. Materi cerita tersebut dapat efektif jika disandingkan dengan faktor pendorong efektivitas cerita, yaitu dikemas dalam judul yang menarik, memiliki intensitas penyampaian, tepat waktu (saat anak relaks dan berada pada gelombang alfa 7-8 sampai $13 \mathrm{~Hz}$ ), gaya bahasa sederhana dan memakai media yang tepat. Adapun faktor yang akan menjadi penghambat efektivitas materi cerita
\end{abstract}


adalah gaya penyampaian bersifat formal, kaku, kering ide, disampaikan secara doktrinasi, durasi tidak tepat, disampaikan pada waktu yang tidak tepat (ketika anak dalam kondisi otak gelombang beta), memakai gaya bahasa menjemukan dan tidak sesuai tahapan perkembangan tingkat intelektual, sosial dan emosional anak. Oleh karena itu, diperlukan sinergitas antara materi cerita dengan faktor pendorong efektivitasnya, sehingga penyampaian materi cerita dapat mencapai tujuan yang diharapkan.

Keywords: materi cerita, kepribadian, perkembangan anak

\section{A. PENDAHULUAN}

Materi cerita memiliki peranan penting dalam pembentukan karakter suatu bangsa. David Mc Clelland yang mengambil Inggris dan Spanyol sebagai bahan penelitian, menyimpulkan bahwa perkembanagan Inggris lebih maju daripada Spanyol. Hal itu karena materi cerita yang berkembang di Inggris pada awal abad ke-16 mengandung virus yang menyebabkan pendengarnya dijangkiti penyakit "butuh berprestasi" (the need for achievement) yang meliputi tiga unsur yaitu optimisme yang tinggi, keberanian mengubah nasib dan sikap tidak gampang menyerah. Sementara dongengdongeng Spanyol lebih meninabobokan. ${ }^{1}$

Selain berpengaruh terhadap pembentukan karakter suatu bangsa, materi cerita juga berdampak terhadap perkembangan anak. Bahkan, akhir-akhir ini para pemerhati anak mulai angkat bicara mengenai cerita-cerita yang dirilis oleh Walt Disney yang lebih banyak memberi pengaruh buruk terhadap anakanak. Margaret Ronnberg dalam jurnalnya membicarakan efek kisah Disney terhadap faktor psikologis anak dari sudut pandang anak-anak. Efek Disney antara lain efek narsisme, efek nostalgia dan membuat

1 Farida Nur"ani. (2010). Membentuk Karakter Anak dengan Dongeng. Surakarta: Indiparent, hlm. 43. segalanya menjadi hiperfantasi dan indah, tapi sesungguhnya membuat orang jadi tidak realistis. $^{2}$

Berkaitan dengan pengaruh materi cerita terhadap anak, Abdullah Nashih Ulwan mengutarakan sebagai berikut:

Metode ini mempunyai pengaruh tersendiri bagi jiwa dan akal, dengan argumentasi-argumentasi yang logis dan rasional. Al-Qur'an memakai metode ini di beberapa tempat, lebihlebih dalam cerita tentang rasul dan kaumnya. Allah telah menceritakan kepada Rasulullah S.A.W. cerita-cerita yang paling baik tentang kejadiankejadian yang baik, sebagai cermin bagi umat manusia dan menjadi peneguh Rasulullah S.A.W. ${ }^{3}$

Di Indonesia sendiri, penggunaan materi cerita dalam pendidikan banyak dilakukan. Beberapa mata pelajaran seperti mata pelajaran Bahasa Indonesia ataupun mata pelajaran Basa Sunda, menjadikan materi cerita bagian materi yang disampaikan kepada anak didik.

Permaslahannya, banyak materi cerita yang bertentangan dengan nilai-nilai Islam.

2 Margareta Ronnberg. ( 2002 ). Whyis Disney So Popular? TheAnimated Feature Films Froma Childish Perspective. Sweden: Filmforlaget, Uppsala, hlm. 7-11.

${ }^{3}$ Abdullah Nashih Ulwan. (2007). Pendidikan Anak dalam Islam. Jakarta: Pustaka Amani, hlm. 222. 
Berdasarkan penelitian Risnawati dan Mujahidin, dari 32 jumlah judul kisah yang dianalisis, 17 judul (53\%) memiliki keterkaitan dengan nilai-nilai Islam, sedangkan 15 judul (47\%) memiliki kontradiksi dengan nilai-nilai Islam tersebut. $^{4}$

Tulisan ini akan mengungkap tentang bagaimana pengaruh materi cerita terhadap perkembangan kepribadian anak dalam perspektif Islam?

\section{B. TINJAUAN PUSTAKA}

\section{Pengertian dan Perkembangan Usia Anak}

Masa kanak-kanak merupakan masa penentu kehidupan seseorang. Keberhasilan pada masa ini akan berdampak pada keberhasilan masa dewasa. ${ }^{5}$ Oleh karena itu, anak-anak kerap kali dianggap sebagai miniatur manusia dewasa. Hurlock menyebutkan anak-anak memiliki emosi kuat yang sering tampak dan bersifat sementara, yang berubah kekuatannya dan dapat diketahui melalui gejala perilaku, umumnya reaksi mencerminkan individualitas. ${ }^{6}$

Ciri khas yang dimiliki tahap ini adalah perkembangan dipusatkan untuk menjadi manusia sosial (belajar bergaul dengan orang lain) karena anak-anak senang mengulang dan senang mencoba hal-hal baru.

\footnotetext{
${ }^{4}$ E. Risnawati dan Endin Mujahidin. (2013). Telaah Materi Dongeng pada Mata Pelajaran Bahasa Sunda Sekolah Dasar (Analisis Kurikulum Bahasa Sunda Sekolah Dasar Berbasis Tauhid). Jurnal Sosial Humaniora, 4 (2).

${ }^{5}$ Endin Mujahidin, et al. (2016). Paradigma Baru Pendidikan Dasar. Bogor: UIKA Press, hlm 1 .

6 Elizabeth B. Hurlock. (1993). PerkembanganAnak. Jakarta: Gelora Aksara Pratama, hlm. 216.
}

Hurlock menyebutkan periode dalam pola perkembangan anak terbagi menjadi 5 (lima) periode yaitu:

a. Periode pra-lahir (sejak pembuahan sampai lahir);

b. Masa neonatus (Lahir sampai 10-14 hari);

c. Masa bayi (2 Minggu sampai 2 tahun);

d. Masa kanak-kanak (2 tahun sampai masa remaja), yang terbagi kepada masa kanak-kanak dini (usia 2-6 tahun) dan akhir masa kanak-kanak (6-13 tahun); dan

e. Masa puber (11-16 tahun). ${ }^{7}$

Ericson menyebutkan dalam tahapan perkembangan kepribadian anak terbagi menjadi:

a. Bayi awal: 0 sampai kurang lebih 1 tahun;

b. Bayi lanjut: kurang lebih 1 sampai 3 tahun;

c. Anak-anak awal: Kurang lebih 4-5 tahun;

d. Anak-anak pertengahan: kurang lebih 6-11 tahun;

e. Masa Puber: kurang lebih 12-20 tahun. $^{8}$

Nasih Ulwan menyebutkan beberapa fase yang dialami oleh anak-anak sebagai berikut:

a. Fase pertama, usia 7-10 tahun, disebut masa tamyiz (masa pra pubertas);

b. Fase kedua, usia 10-14 tahun, disebut masa murahaqah (masa peralihan atau masa pubertas);

c. Fase ketiga, usia 14-16 tahun, disebut masa bulugh (masa adolesen);

7 Elizabeth B. Hurlock.

(1993).

Perkembangan Anak. hlm. 39.

${ }^{8}$ Djaali. (2009). Psikologi Pendidikan. Jakarta: Bumi Aksara, hlm. 8. 
d. Fase keempat, masa setelah masa adolesen, disebut masa pemuda. ${ }^{9}$

Adapun pertumbuhan dan perkembangan anak sebagai manusia dijelaskan secara gamblang dan lugas dalam Al-Qur'an Surat Al-Mu'minun Ayat 12-16, yaitu pertama, masa nutfah (tetesan sperma, spermatozoa); kedua, masa 'alaqoh (gumpalan darah yang melekat pada dinding rahim); ketiga, masa mudhghah (gumpalan daging); keempat, masa idzam (terbentuknya tulang yang terbalut daging, jaringan dan otot; dan kelima, masa janin terbentuk sempurna. $^{10}$

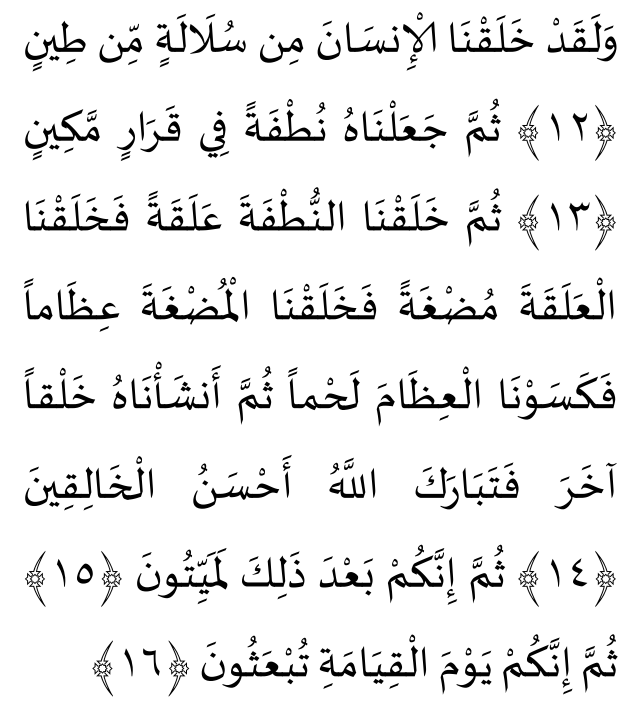

Dan Sesungguhnya Kami telah menciptakan manusia dari suatu saripati (berasal) dari tanah. Kemudian Kami jadikan sari pati itu air mani (yang disimpan) dalam tempat yang kokoh (rahim). Kemudian air mani itu Kami jadikan segumpal darah, lalu segumpal darah itu Kami jadikan segumpal daging, dan segumpal

${ }^{9}$ Abdullah Nashih Ulwan. (1981). Pedoman Pendidikan Anak dalam Islam. Semarang: AsSyifa, hlm. 572.

10 Baharuddin. (2009). Pendidikan dan Psikologi Perkembangan. Jogjakarta: Ar-Ruzz Media, hlm. 84. daging itu Kami jadikan tulang belulang, lalu tulang belulang itu Kami bungkus dengan daging. Kemudian Kami jadikan Dia makhluk yang (berbentuk) lain. Maka Maha sucilah Allah, Pencipta yang paling baik. Kemudian, sesudah itu, Sesungguhnya kamu sekalian benar-benar akan mati. Kemudian, Sesungguhnya kamu sekalian akan dibangkitkan (dari kubur mu) di hari kiamat.

Perkembangan selanjutnya dijelaskan dalam Al-Qur'an Surat Al-Hajj Ayat 5:

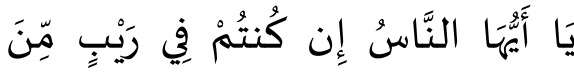

$$
\begin{aligned}
& \text { الْبَعْثِ فَإِنَّا خَلَقْنَاكُمَ هِنْ تُرَابٍ ثُمَّمُ مِن }
\end{aligned}
$$

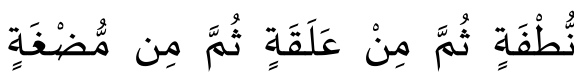

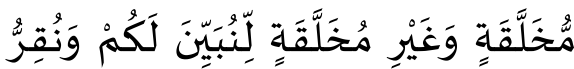

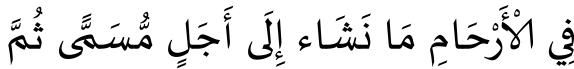

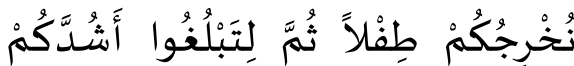

$$
\begin{aligned}
& \text { وَمِنكُم مَّن يُنَتَفََّّ وَمِنكُم مَّن يُرَدُّ إِلَى }
\end{aligned}
$$

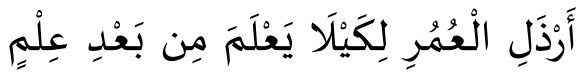

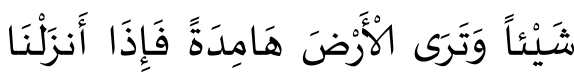

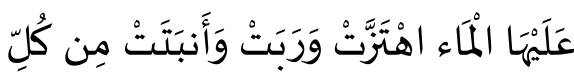

$$
\begin{aligned}
& \text { زَوْجِ بَهِيجِ }
\end{aligned}
$$

Hai manusia, jika kamu dalam keraguan tentang kebangkitan (dari kubur), Maka (ketahuilah) Sesungguhnya Kami telah menjadikan kamu dari tanah, kemudian dari setetes mani, kemudian dari segumpal darah, kemudian dari segumpal daging yang sempurna kejadiannya dan 
yang tidak sempurna, agar Kami jelaskan kepada kamu dan Kami tetapkan dalam rahim, apa yang Kami kehendaki sampai waktu yang sudah ditentukan, kemudian Kami keluarkan kamu sebagai bayi, kemudian (dengan berangsur-angsur) kamu sampailah kepada kedewasaan, dan diantara kamu ada yang diwafatkan dan (adapula) diantara kamu yang dipanjangkan umurnya sampai pikun, supaya dia tidak mengetahui lagi sesuatupun yang dahulunya telah diketahuinya. Dan kamu lihat bumi ini kering, kemudian apabila telah Kami turunkan air di atasnya, hiduplah bumi itu dan suburlah dan menumbuhkan berbagai macam tumbuhtumbuhan yang indah."

Hannan Athiyah Ath Thuri menyebutkan fase pertumbuhan manusia sebagai berikut: ${ }^{11}$

a. Fase pra kelahiran, dimulai saat terjadinya kehamilan dan berakhir dengan kelahiran. Umumnya adalah sembilan bulan;

b. Fase menyusui (radha'ah), mencakup dua minggu pertama kehidupan bayi dan berakhir pada usia dua tahun;

c. Fase kanak-kanak dini (hadhanah), dimulai dari usia tiga tahun sampai akhir usia lima tahun. Fase kedua dan ketiga ini disebut dengan fase pra sekolah;

11 Hannan Athiyah Ath-Thuri. (2007). Mendidik Anak Perempuan di Masa Kanak-Kanak. Jakarta: AMZAH, hlm. xi-xii. d. Fase kanak-kanak pertengahan, dari usia enam hingga delapan tahun. Ini setara dengan tiga kelas pertama sekolah dasar;

e. Fase kanak-kanak akhir, mulai usia sembilan hingga dua belas tahun. Ini sebanding dengan tiga kelas terakhir sekolah dasar. Para Ahli fikih menyebutkan fase keempat dan kelima dengan istilah tamyiz;

f. Fase remaja (murahaqah), biasanya usia 13-18 tahun;

g. Fase muda, usia 18-24 tahun. Fase ini sejajar dengan rentang waktu pendidikan tinggi dan merupakan fase yang memiliki ragam problematika yang terkait orientasi kerja dan pendidikan;

h. Fase dewasa, usia 25-64 tahun

Fase tua, berkisar antara 65-70 tahun dan berbeda-beda antar setiap orang.

Baharuddin menyebutkan masa perkembangan manusia meliputi: (1) masa bayi dan anak-anak (thifl), yaitu masa sejak persalinan hingga menjadi anak-anak yang mulai beranjak dewasa; (2) masa baligh hingga dewasa (litablughuasyuddakum) yaitu masa ketika terjadi perubahan mendasar dalam kehidupan; (3) masa Tua (usia lanjut), yaitu keadaan seseorang saat melewati masa puncak kekuatan fisik lalu menurun kembali menjadi tidak berdaya, ${ }^{12}$ seperti yang dijelaskan dalam Al-Qur'an Surat Al-Hajj Ayat22:

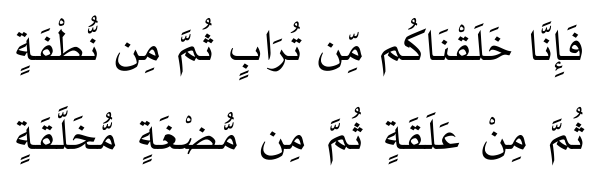

12 Hannan Athiyah Ath-Thuri. (2007). Mendidik Anak Perempuan di Masa Kanak-Kanak. Jakarta: AMZAH, hlm. xi-xii. 


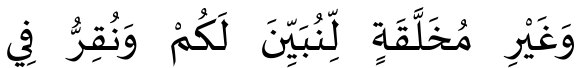

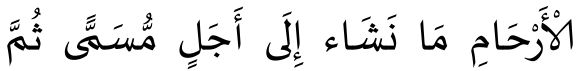

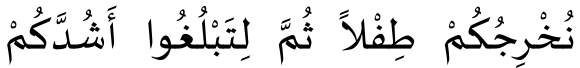

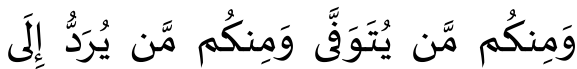
أَرْذَلِ الْعُمُرِ لِكَيْلَا يَعْلَمَ مِن بَعْدِ عِلْهِ

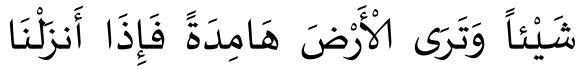
عَلَيْهَا الْمَاء اهْتَزَّتْ وَرَبَتْ وَأَنَبَتَتْ مِن كُلِِّ

$$
\text { زَوْجِ بَهيجِ }
$$

Maka (ketahuilah) sesungguhnya Kami telah menjadikan kamu dari tanah, kemudian dari setetes mani, kemudian dari segumpal darah, kemudian dari segumpal daging yang sempurna kejadiannya dan yang tidak sempurna, agar Kami jelaskan kepada kamu dan Kami tetapkan dalam rahim, apa yang Kami kehendaki sampai waktu yang sudah ditentukan, kemudian Kami keluarkan kamu sebagai bayi, kemudian (dengan berangsur-angsur) kamu sampailah kepada kedewasaan, dan di antara kamu ada yang diwafatkan dan (ada pula) di antara kamu yang dipanjangkan umurnya sampai pikun, supaya dia tidak mengetahui lagi sesuatupun yang dahulunya telah diketahuinya. Dan kamu lihat bumi ini kering, kemudian apabila telah Kami turunkan air di atasnya, hiduplah bumi itu dan suburlah dan menumbuhkan berbagai macam tumbuhtumbuhan yang indah.
Dari penjelasan di atas dapat disimpulkan bahwa usia anak yang sangat kondusif untuk menerima materi cerita adalah usia tamyiz sampai menjelang bulugh.

\section{Pengertian Kepribadian}

Kepribadian (Personality) adalah suatu organisasi yang dinamis dari system psikofisis dalam individu yang menentukan keunikan penyesuaian diri terhadap lingkungan. ${ }^{13}$ Sistem psikofisis adalah keseluruhan fisik psikologis yang dimiliki seseorang. Faktor fisik seperti bentuk tubuh dan faktor genetika sedangkan faktor psikologis adalah intelegensi, minat, motivasi, perasaan.

Menurut Hary Stack Sullivan, kepribadian adalah pola yang relatif dari situasi hubungan antara person yang ditandai kehidupan manusia. Kepribadian tidak dapat dipisahkan dari situasi hubungan antara seseorang dengan orang lain. $^{14}$

Djaali menjelaskan bahwa secara umum dapat dikatakan bahwa kepribadian merupakan suatu proses dinamis di dalam diri, yang terus menerus dilakukan terhadap system psikofisik (fisik dan mental), sehingga terbentuk pola penyesuaian yang unik atau khas pada setiap orang terhadap lingkungan. ${ }^{15}$

Begitu banyak definisi kepribadian yang telah disebutkan oleh para ahli psikologi, namun Elizabeth Hurlock menyebutkan bahwa untuk benar-benar memahami pengertian kepribadian,

\footnotetext{
${ }^{13}$ Pasaribu dan Simandjuntak. (1984). Teori Kepribadian. Bandung: Tarsito, hlm. 95.

${ }^{14}$ Pasaribu dan Simandjuntak. (1984). Teori Kepribadian. Bandung: Tarsito, hlm. 102.

15 Djaali. (2009). Psikologi Pendidikan. Jakarta: Bumi Aksara,hlm3.
} 
kerumitan struktur dan semua pengaruh yang meresap terhadap keseluruhan kualitas perilaku individu, seseorang harus memahami aspek motivasi. Hal ini menjadi jelas bila seseorang memikirkan kesan palsu yang sering ia dapat dari penilaian hanya didasarkan pada aspek nyata kepribadian berupa perkataan individu, perilaku, dan penampilannya.

To understand what the personality is, the intricacy of its structure and its all pervasive influence on the quality of the individual total behavior. one must understand its motivational aspect. This become apparent when on econsiders what afalse impression one of tengets from judgments based solely on the manifest aspect of personality, the individuals peech, behavior and appearance. ${ }^{16}$

Dalam kamus bahasa Arab modern, istilah syakhsiyyah digunakan untuk menyebut personality (kepribadian). ${ }^{17}$ Syakhsiyyah atau kepribadian secara istilah memiliki arti lebih luas dan mendalam dibandingkan makna karakter dan akhlak. Abdul Mujib menyatakan bahwa term syakhsiyyah telah menjadi kesepakatan umum untuk menyebut kepribadian dalam literatur Islam modern. Sekalipun kata syakhsiyyah tidak dipakai dalam literatur Islam klasik dikarenakan kata ini memang tidak ditemukan dalam Al-Qur'an dan AlSunnah.

Dengan demikian, kepribadian pada hakikatnya merujuk pada sifat-sifat yang dimiliki secara spesifik oleh seseorang. Dalam konteks kepribadian anak, sifat-sifat

${ }^{16}$ Elizabeth B. Hurlock. (1993). Perkembangan Anak. Jakarta: Gelora Aksara Pratama, hlm. 35.

17 Abdul Mujib. 2006. Kepribadian dalam Psikologi Islam. Jakarta: Raja Grafindo Persada, hlm. 25. spesifik tersebut bisa dalam bentuk sifat berani, jujur, pantang menyerah, dan sebagainya.

\section{Faktor-Faktor yang Mempengaruhi Kepribadian}

Kepribadian tumbuh dan berkembang dengan bebeberapa faktor tertentu yang mempengaruhinya, antara lain kemampuan, kebudayaan, keluarga dan sikap orangtua. ${ }^{18}$

Faktor-faktor yang mempengaruhi kepribadian berasal dari faktor internal dan faktor eksternal. Faktor internal adalah faktor yang berasal dari dalam diri, sedangkan faktor eksternal adalah faktor yang berasal dari luar diri. Yang termasuk faktor internal adalah warisan biologis (genetik) dari orangtua dan pengalaman yang didapat selama hidupnya. Sedangkan faktor eksternal terdiri dari lingkungan budaya dan lingkungan fisik. Elizabeth B. Hurlock menyebutkan bahwa perkembangan kepribadian dipengaruhi oleh faktor genetik selain juga oleh sikap dan hubungan sosial, baik di rumah maupun di luar rumah. ${ }^{19}$

Teori Konvergensi Stern yang diungkapkan oleh William Stern, menyatakan bahwa segala sesuatu dari perkembangan anak merupakan produk interaksi antara faktor hereditas dan faktor lingkungan sosialnya. ${ }^{20}$ Kedua faktor ini harus bekerjasama agar perkembangan

${ }^{18}$ Djaali. 2009. Psikologi Pendidikan. Jakarta: Bumi Aksara, hlm. 95.

${ }^{19}$ Elizabeth B. Hurlock. (1993). Perkembangan Anak. Jakarta: Gelora Aksara Pratama, hlm 35.

${ }^{20}$ Syailendra Putra. (2009). Anakku Bertingkah Seperti Sponge Bob, Siasat Mendampingi Anak Anda dalam Menonton Film Kartun. Jakarta: Pustaka Widyamara, hlm. 43. 
berlangsung sehat sehingga mendorong berfungsinya segenap kemampuan anak.

Stern mengatakan bahwa pribadi manusia dibentuk oleh faktor luar dan dalam sehingga perkembangan pribadi manusia dipengaruhi oleh diri manusia sendiri dan faktor lingkungannya. ${ }^{21}$

Faktor-faktor lingkungan yang disebutkan oleh Stern antara lain faktor sosial meliputi keluarga, sekolah, dan masyarakat. Bahkan hewan dan tumbuhan serta cuaca termasuk faktor non sosial yang mempengaruhi. Terlebih lagi budaya berupa bahasa, lagu, undangundang, dan sebagainya merupakan faktor tak berwujud yang mempengaruhi perkembangan pribadi anak.

\section{Pengertian Cerita}

Semua budaya lisan menggunakan cerita, dan semua jenis cerita budaya itu memegang peran penting dalam kehidupan dari masyarakatnya. ${ }^{22}$ Kieran Egan menyatakan bahwa

Cerita adalah instrument untuk mengorientasikan emosi manusia terhadap isi cerita itu. Cerita tidak hanya sekedar menyampaikan informasi tentang kejadian dan karakter atau hanya sekedar menyampaikan informasi dengan cara melibatkan emosi, cerita mengarahkan atau membentuk emosi terhadap kejadian dan karakter dengan cara tertentu. Jadi jenis makna cerita yang disampaikan oleh cerita-cerita itu berkaitan dengan emosi"

${ }^{21}$ Syailendra Putra. (2009). Anakku Bertingkah Seperti Sponge Bob, Siasat Mendampingi Anak Anda dalam Menonton Film Kartun. Jakarta: Pustaka Widyamara, hlm. 44.

${ }^{22}$ Kieran Egan. (2009). Pengajaran Yang Imajinatif (An Imaginative Approach to Teaching). Jakarta: Indeks, hlm. 10.
Cerita adalah tuturan yang membentangkan bagaimana terjadinya suatu peristiwa, kejadian dan sebagainya.; karangan yang menuturkan perbuatan, pengalaman, penderitaan orang; lakon yang diwujudkan dalam gambar hidup (sandiwara, wayang dan sebagainya; omong kosong, dongengan yang tidak dijamin kebenarannya. Cerita ada bermacam-macam antara lain cerita berantai, cerita bingkai, cerita bersambung, cerita burung, cerita pendek, cerita rakyat, cerita rekaan, cerita sejarah. ${ }^{23}$

Kieran Egan menjelaskan bahwa cerita merupakan salah satu alat-alat kognisi primer yang paling ampuh yang dimiliki oleh para siswa, yang bersedia untuk keterlibatan imajinatif dengan ilmu pengetahuan. $^{24}$

Cerita merupakan salah satu cara paling efektif untuk mengemukakan informasi sosial yang penting dalam bentuk yang mudah diingat, maka cerita digunakan secara universal. Selain itu cerita dapat membentuk emosi pendengar sebagai jawaban terhadap isi cerita itu dan hanya cerita yang dapat berbuat begitu. Cerita tidak berlalu begitu si pengguna bertambah tua. $^{25}$

Cerita merupakan sebuah proses penyampaian informasi yang sungguh luar biasa. Kekuatan cerita yang melibatkan unsur emosi, seringkali lebih kuat pengaruhnya daripada pemaparan

${ }^{23}$ Em Zul Fajri dan Ratu Aprilia Senja, t.t. Kamus Lengkap Bahasa Indonesia. Jakarta: Difa Publiser, hlm. 213.

${ }^{24}$ Kieran Egan. (2009). Pengajaran Yang Imajinatif (An Imaginative Approach to Teaching). Jakarta: Indeks, hlm. 3.

25 Kieran Egan. (2009). Pengajaran Yang Imajinatif (An Imaginative Approach to Teaching). Jakarta: Indeks, hlm. 12. 
referensial atau informasi formal. Melalui cerita, pesan moral, informasi yang bersifat pengetahuan, wawasan dan hubungan emosional yang lebih berkualitas dapat lebih mudah disampaikan. ${ }^{26}$

\section{METODE PEMBAHASAN}

Metode yang digunakan dalam pembahasan ini adalah metode pustaka (library research). Metode ini menggunakan langkah dengan mengumpulkan data dan informasi dengan bantuan berbagai materi yang terdapat dalam perpustakaan mulai dari buku-buku referensi, jurnal ilmiah, media massa (koran dan majalah) hingga media elektronika (micro film, laman-laman yang dapat dipercaya). Pendekatan yang digunakan adalah pendekatan kualitatif dengan analisis yang digunakan adalah deskriptif analisis dengan tahapan sebagai berikut:

1. Mencari dan meneliti data pustaka yang menjelaskan tentang anak dan perkembangannya termasuk perkembangan kepribadiannya;

2. Mencari dan meneliti data pustaka yang menjelaskan tentang berbagai metode cerita dan manfaatnya bagi perkembangan anak;

3. Mencari dan meneliti data pustaka yang menjelaskan tentang berbagai pengaruh cerita terhadap perkembangan kepribadian anak;

4. Mencari dan meneliti data pustaka yang menjelaskan tentang reorientasi materi cerita.

${ }^{26}$ Nurul F. Huda. (2010). Kiat Membentuk Anak Berkarakter Hebat. Yogyakarta: Bidadari Biru, hlm. 79.

\section{HASIL DAN PEMBAHASAN}

Hampir semua anak menyukai cerita sehingga menjadi salah satu media dilembaga pendidikan. Usia emas perkembangan fisik, motorik, psikis, dan kognitif mereka dapat dioptimalkan dengan menggunakan cerita sebagai sarana informasi positif terkait kebutuhan perkembangan unsur-unsur diatas. ${ }^{27}$

Materi cerita memang mampu mempengaruhi jalan pikiran seseorang. Bukan sekedar itu, ia mampu melahirkan keyakinan dan membentuk karakter seseorang bahkan suatu umat. ${ }^{28}$ Sangat kuatnya pengaruh materi cerita terhadap suatu umat dapat dilihat dari firman Allah S.W.T. Surat Al-Baqarah Ayat 170:

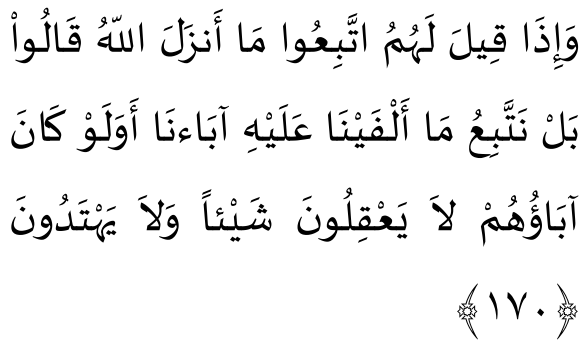

Dan apabila dikatakan kepada mereka: "Ikutilah apa yang telah diturunkan Allah," mereka menjawab: "(Tidak), tetapi Kami hanya mengikuti apa yang telah Kami dapati dari (perbuatan) nenek moyang kami". "(Apakah mereka akan mengikuti juga), walaupun nenek moyang mereka itu tidak mengetahui suatu apapun, dan tidak mendapat petunjuk?

${ }^{27}$ Nurul F. Huda. (2010). Kiat Membentuk Anak Berkarakter Hebat. Yogyakarta:, Bidadari Biru, hlm 79.

28 Hawari. (2010). Bukan Dongeng Tapi Kisah Sebelum Tidur. Jakarta: Majalah Gerimis, 10/XI/2011, hlm. 18. 
Ayat tersebut menjelaskan bahwa penolakan suatu kaum terhadap ajaran para nabi utusan Allah adalah semata mereka hanya mengikuti perbuatan yang dicontohkan dan dilakukan oleh nenek moyang, walaupun nenek moyang mereka tidak mendapat petunjuk.

\section{Materi Cerita dalam Al-Qur'an}

Dalam tiap tahapan usia, anak akan menyukai dan menaruh minat pada cerita yang berbeda. Untuk anak usia taman kanak-kanak, cerita dengan tokoh binatang (fabel) merupakan cerita yang paling diminati, sementara anak usia 5-7 mulai menyukai cerita yang berisi petualangan dan cerita kepahlawanan dalam cerita rakyat. Sedangkan untu kanak yang berusia lebih tinggi, mulai menyukai cerita dengan latar belakang pengalaman hebat (avontur) dan cerita kepahlawanan (saga) dengan latar belakang ilmu pengetahuan (sains) yang mencekam dan penuh tantangan.

Jika seorang David C.Mc Clelland dapat menjelaskan bahwa cerita dapat mempengaruhi kejayaan sebuah bangsa, maka sesungguhnya Allah dan Rasul-Nya telah menjelaskan tentang hal ini bahwasanya setiap cerita yang disampaikan dalam Al-Qur'an adalah agar manusia berfikir. Dalam Al-Qur'an Surat Al-A'raaf Ayat 176:

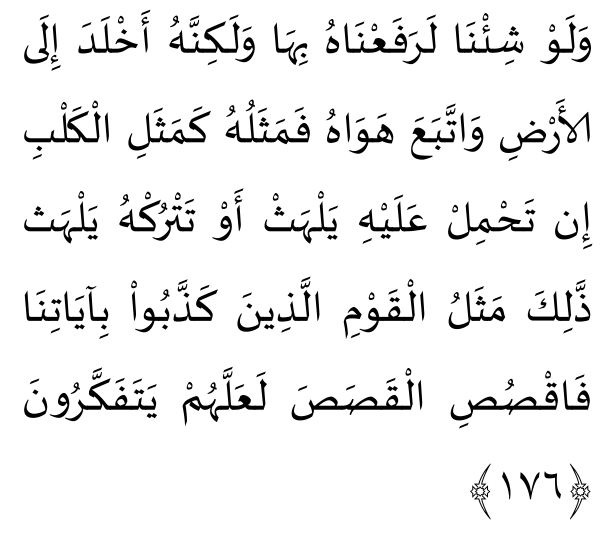

Dan kalau Kami menghendaki, sesungguhnya Kami tinggikan (derajat) nya dengan ayat-ayat itu, tetapi dia cenderung kepada dunia dan mengikuti hawa nafsunya yang rendah, maka perumpamaannya seperti anjing jika kamu menghalaunya diulurkannya lidahnya dan jika kamu membiarkannya dia mengulurkan lidahnya (juga). Demikian itulah perumpamaan orang-orang yang mendustakan ayat-ayat Kami. Maka ceritakanlah (kepada mereka) kisah-kisah itu agar mereka berfikir.

Selain itu, materi cerita juga untuk memperteguh hati serta untuk pengajaran dan peringatan bagi orang-orang yang beriman. Dalam Al-Qur'an Surat Hud Ayat 120, Allah S.W.T. berfirman:

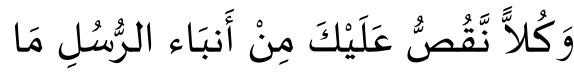

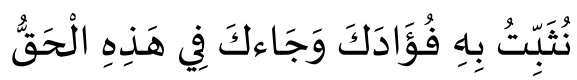

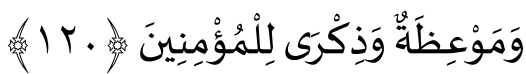

Dan semua kisah dari rasul-rasul Kami ceritakan kepadamu, ialah kisah-kisah yang dengannya Kami teguhkan hatimu; dan dalam surat ini telah datang kepadamu kebenaran serta pengajaran dan peringatan bagi orang-orang yang beriman.

Islam mengenal berbagai materi cerita yang sangat menarik. Dalam Al-Qur'an diceritakan tentang para nabi dan orangorang yang sholeh. Begitu pula diceritakan kisah umat yang membangkang terhadap para utusan Allah, seperti Kaum Tsamud (Al-Qur'an Surat Asy Syu'araa Ayat 141- 
159), Kaum Aad (Al-Qur'an surat Asy Syu'araa Ayat 123-140), Kaum Luth (AlQur'an Surat Asy Syu'araa Ayat 160-175, surat Al-Ankabuut ayat 28-35), kisah Fireaun (Al-Qur'an Surat Al-A'raaf Ayat 103-136; Surat Asy-Syu'araa Ayat 10-51; Surat Al-Mu'minun Ayat 21-37, Surat AlQashash Ayat 38-42, Surat An-Naaziaat Ayat 15-26), Qarun (Al-Qur'an Surat SlQashash Ayat 76-82).

Kisah-kisah hewan-hewan yang dapat menjadi inspirasi bagi manusia seperti kisah lebah (Al-Qur'an Surat An-Nahl Ayat: 68-69). Dan kisah tentang dialog antar semut (QS. An-Naml Ayat 16-19) yang merupakan dua binatang yang namanya dijadikan nama surah dalam AlQur'an.

Selain itu ada pula kisah dialog burung Hud hud dengan Nabi Sulaiman (AlQur'an Surat An-Naml Ayat 20-28). AlQur'an juga menceritakan kisah antar manusia seperti kisah guru dengan murid antara Nabi Musa dengan Nabi Khidir (AlQur'an Surat Al-Kahfi Ayat 65-82), dialog antara orang tua dan anak, antara lain antara Nabi Ibrahim dengan Nabi Ismail (Al-Qur'an Surat Ash-Shaafaat Ayat 02, dan Lukman dengan anaknya (Al-Qur'an Surat Luqman Ayat 12-19).

Banyaknya kisah yang terdapat di dalam Al-Qur'an mengajarkan kepada umat Islam agar tidak menggunakan materi cerita yang berisi kebohongan. Al-Qur'an telah meyakinkan manusia bahwa dongengan adalah bohong belaka dan hanya berisi dugaan-dugaan. Hal tersebut telah dinyatakan dalam QS. Al-Baqarah Ayat 78:

$$
\begin{aligned}
& \text { وَمِنْهُمْ أُمِيُّونَ لَا يَعْلَمُونَ الْكِتَابَ إِلَّ }
\end{aligned}
$$

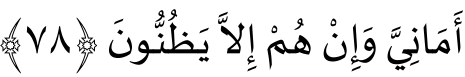

Dan di antara mereka ada yang buta huruf, tidak mengetahui $\mathrm{Al}$ Kitab (Taurat), kecuali dongengan bohong belaka dan mereka hanya menduga-duga.

Jika saat ini kepribadian anak banyak yang sudah terkontaminasi oleh materi cerita yang tidak baik dan penuh kebohongan, namun masih dapat diubah dan dibentuk kembali menjadi kepribadian yang baik dan Islami.

\section{Pengaruh Materi Cerita Terhadap Perkembangan Anak}

Metode bercerita memiliki beberapa keunggulan, selain just for fun juga sangat potensial karena dapat menyelipkan nilainilai khusus seperti pesan dan nasehat, karena anak tidak suka mendengar nasehat yang terlalu panjang. ${ }^{29}$ Bercerita dapat dilakukan dimana saja, kapan saja, dalam situasi apapun dan tidak memerlukan biaya. Farida Nur'aini, seorang ibu pemerhati pendidikan menyebutkan beberapa manfaat bercerita, sebagai berikut: ${ }^{30}$

a. Bercerita merupakan ajang yang tepat untuk mengenalkan berbagai kehidupan;

b. Mengenalkan lingkungan di sekitarnya maupun di luar lingkungannya;

c. Mengenalkan anak pada kosa kata baru;

d. Sarana memperkenalkan teknologi;

\footnotetext{
${ }^{29}$ Farida Nur'aini. (2009). Dongengin Aku Yuk!. Surakarta: Afra Publising, hlm. 29.

${ }^{30}$ Farida Nur'aini. (2010). Membentuk Karakter Anak dengan Dongeng. Surakarta: Indiparent, hlm 32.
} 
e. Mengenalkan sensitivitas terhadap permasalahan;

f. Mengembangkan perbendaharaan kosa kata;

g. Melatih kemampuan visualisasi;

h. Membantu pembentukan pribadi dan moral anak;

i. Menyalurkan kebutuhan imajinasi dan fantasi;

j. Memacu kemampuan verbal anak;

k. Merangsang minat menulis anak;

1. Merangsang minat baca anak;

m. Membuka cakrawala pengetahuan anak.

Melalui bercerita, daya fantasi anakanak berkembang sehat. Alur cerita bisa diatur menurut kehendak mereka sendiri. Setiap anak butuh pengembangan imajinasi dan cerita merupakan sarana paling tepat untuk itu. ${ }^{31}$

Kegiatan bercerita sangat disukai dan selalu dinanti-nantikan oleh anak-anak. Kegiatan ini bisa menjadi sarana efektif untuk menanamkan nilai dan pendidikan moral. Tanpa terasa digurui, anak-anak dapat menyerap nilai-nilai moral yang diajarkan oleh sebuah cerita sehingga membekas dalam hatinya. Nilai moral yang disampaikan melalui ceritajauh lebih efektif dibandingkan dengan nasehat biasa. $^{32}$

Kusumo Priyono Ars seorang ahli mendongeng, menyebutkan bahwa bercerita bertujuan untuk: ${ }^{33}$

a. Memperkaya pengalaman batin anak dan menstimulir reaksi sehat atasnya;

\footnotetext{
${ }^{31}$ Irawati Istadi. (2006). Mendidik dengan Cinta. Bekasi: Pustaka Inti, hlm. 113.

${ }^{32}$ Irawati Istadi. (2006). Mendidik dengan Cinta. Bekasi: Pustaka Inti, hlm. 113.

${ }^{33}$ Irawati Istadi. (2006). Mendidik dengan Cinta. Bekasi: Pustaka Inti, hlm. 15.
}
b. Merangsang dan menumbuhkan imajinasi dan daya fantasi secara wajar;
c. Mengembangkan daya penalaran sikap kritis serta kreatif;

d. Mempunyai sikap kepedulian terhadap nilai-nilai luhur budaya bangsa;

e. Dapat membedakan perbuatan yang baik dan perlu ditiru, dengan perbuatan yang buruk dan tidak perlu dicontoh;

f. Memiliki rasa hormat dan mendorong terciptanya kepercayaan diri dan sikap terpuji bagi anak-anak.

Manfaat lain adalah mampu mencetak anak yang gemar membaca, berani berbicara, mampu mengungkapkan cerita bahkan mampu menciptakan dongengdongeng lainnya dari dongeng yang mereka dengar atau baca. ${ }^{34}$

Saat bercerita selain terjadi transfer nilai, terjalin juga kedekatan antara orang tua dan anak. Ketika mendengar cerita dari orangtua, anak-anak akan merasa semakin dekat dan terikat dengan orangtuanya. ${ }^{35}$

Nicole Niamic mengatakan: "Jika orangtua membacakan buku cerita kepada anak sejak dini, mereka sebenarnya telah mengenalkan anak pada dunia lain yang mengasyikkan". ${ }^{36}$ Lebih lanjut, kebiasaan membacakan cerita akan menentukan kesuksesan anak-anak dikemudian hari. Anak usia 2 (dua) tahun yang setiap hari

34 Rohinah M. Noor. (2011). .Pendidikan Karakter Berbasis Sastra, Solusi Pendidikan Moral yang Efektif. Jogjakarta: Ar Ruzz Media, hlm 49.

${ }^{35}$ Asmawati. (2009). .Dongeng Bunda Cerahkan Masa Depan Anak. Jakarta, Majalah Ummi, No.08/XXI, hlm. 109.

${ }^{36}$ Pustaka Lebah. (2010). Around The World Amazing Stories of Great Sites Book ThreeAmerica. Jakarta: Pustaka Lebah, hlm. 1. 
sering dibacakan buku cenderung berprestasi lebih baik ketika di TK dan SD serta memiliki kemampuan belajar dan komunikasi lebih baik dibanding anak lainnya. $^{37}$

Tiga orang peneliti berkebangsaan Jerman yaitu H.G Wahn, W. Hesse dan U. Schaefer memperoleh kesimpulan bahwa anak-anak yang sering didongengi

Biasanya tumbuh menjadi anak yang lebih pandai, lebih tenang, lebih terbuka dan lebih seimbang jika dibandingkan dengan anak-anak yang tidak didongengi. ${ }^{38}$

Lebih lanjut mereka mengungkapkan bahwa imajinasi, perbendaharaan kata, daya ingat dan cara bicara berkembang sesuai dengan kesan-kesan pendengaran dan pengamatan yang diperoleh anak melalui dongeng. ${ }^{39}$

Kieran Egan dalam salah satu bukunya menyatakan bahwa cerita membentuk pemahaman emosional terhadap isi. Cerita dapat membentuk dunia nyata dan juga materi fiksional. Pembentukan cerita dunia nyata inilah yang menjanjikan nilai paling besar dari pengajaran. ${ }^{40}$

Kekuatan besar dari cerita adalah bahwa mereka dapat melakukan dua tugas sekaligus dalam waktu yang bersamaan. Pertama, cerita sangat efektif dalam mengkomunikasikan informasi dengan

${ }^{37}$ Pustaka Lebah. (2010). Around The World Amazing Stories of Great Sites Book ThreeAmerica. Jakarta: Pustaka Lebah, hlm. 1.

${ }^{38}$ Rohinah M. Noor. 2011. Pendidikan Karakter Berbasis Sastra, Solusi Pendidikan Moral yang Efektif. Jogjakarta: Ar Ruzz Media, hlm. 49.

39 Rohinah M. Noor. (2011). Pendidikan Karakter Berbasis Sastra, Solusi Pendidikan Moral yang Efektif. Jogjakarta: Ar Ruzz Media, hlm. 49.

${ }^{40}$ Kieran Egan. (2009). Pengajaran Yang Imajinatif (An Imaginative Approach to Teaching). Jakarta: Indeks, hlm. 3. bentuk yang mudah diingat, dan kedua, cerita dapat mengarahkan perasaan pendengarnya tentang informasi yang dikomunikasikan. $^{41}$

\section{Faktor pendorong pengaruh cerita pada anak}

Sebuah cerita akan menjadi sangat berpengaruh bagi anak dan sebuah kisah akan semakin menarik simpati anak apabila: ${ }^{42}$

a. Pemilihan tema atau judul yang menyenangkan bagi anak. Dengan judul yang menarik dan alur cerita yang menarik akan membuat anak senang dan tidak bosan mengikuti cerita dan selalu bersemangat untuk mendengarkan atau membaca cerita tersebut berulang kali;

b. Materi cerita disampaikan secara terus menerus secara berkesinambungan secara menyenangkan, misalnya memberikan kisah sebelum anak tidur. Namun hendaknya cerita tidak hanya disampaikan saat menjelang tidur saja, melainkan juga saat-saat luang untuk mempererat kasih sayang orang tua dan anak;

c. Penggunaan gaya bahasa yang sesuai dengan tingkat pemahaman anak. Bahasa anak tentunya harus sederhana dan mudah dimengerti. Sehingga anak akan mendengarkan dengan baik dan memahaminya.

d. Pemilihan waktu dan menentukan durasi waktu yang tepat. Hendaknya

${ }^{41}$ Kieran Egan. (2009). Pengajaran Yang Imajinatif (An Imaginative Approach to Teaching). Jakarta: Indeks, hlm. 12.

${ }^{42}$ Hawari. (2010). Bukan Dongeng Tapi Kisah Sebelum Tidur. Jakarta: Majalah Gerimis, Vol.10/XI/2011, hlm. 19. 
tidak terlalu panjang dan tidak terlalu singkat. Jim Trelease menyatakan bahwa rentang perhatian bayi saat orang tua membacakan cerita rata-rata hanya sekitar tiga menit, meski demikian akumulasi waktu membaca diberbagai kesempatan dalam satu hari mencapai tiga puluh menit. Lebih lanjut ia mengatakan bahwa membacakan cerita kepada anak-anak selama sepuluh menit dengan penuh perhatian dan antuasias, mungkin bisa bertahan dalam waktu yang lebih lama di dalam benak anak. ${ }^{43}$

Keberhasilan sebuah cerita dalam mempengaruhi seorang anak tidak hanya ditentukan oleh daya rangsang imajinasinya, melainkan juga kesadaran dan kemampuan pencerita/pendongeng untuk menyajikannya secara lebih menarik dengan intonasi dan tempo yang sesuai dengan cerita.

Para ahli syaraf telah menemukan adanya gelombang dalam otak yang dihasilkan oleh muatan listrik. Gelombang ini dapat diukur dengan menggunakan alat EEG (Electroencep halogragh). Awalnya pengukuran gelombang otak ini dimaksudkan untuk mengetahui diagnosis gangguan otak. Namun kini pengetahuan tentang kondisi tertentu yang menimbulkan gelombang otak tertentu akan memudahkan seseorang bekerja pada keadaan yang prima

Taufik Pasiak menyebutkan bahwa keadaan gelombang otak yang baik sekali untuk belajar adalah gelombang alfa. ${ }^{44}$

\footnotetext{
${ }^{43}$ Jim Trelease. (2008). Read Aloud Handbook; Mencerdaskan Anak dengan Membacakan Cerita Sejak Dini. Jakarta: Hikmah, hlm. 74.

${ }^{44}$ Taufik Pasiak. (2002). Revolusi IQ/EQ/SQ Menyingkap Rahasia kecerdasan Berdasarkan Al Qur"an dan Nerurosains Mutakhir. Jakarta: Mizan, hlm. 220.
}

Untuk mencapai tahapan otak berada dalam keadaan gelombang alfa, lebih lanjut ia menyebutkan bahwa ketika tubuh bereaksi dalam bentuk keadaan relaksasi, otak menampakkan gelombang alfa. ${ }^{45}$ Yang memiliki kisaran gelombang 7-8 sampai dengan $13 \mathrm{~Hz}^{46}$

Relaksasi adalah respon tubuh yang ditandai oleh adanya ketenangan perasaan dan kejernihan pikiran. ${ }^{47}$ Respon relaksasi terjadi melalui penurunan kebutuhan terhadap oksigen, kerja tubuh menjadi ringan, metabolisme berkurang. Dalam kondisi relaks, otak dalam keadaan jernih namun tetap siaga untuk melakukan sesuatu sehingga tubuh dalam keadaan sehat dan akan membuka informasi bawah sadar manusia sekitar $88 \%{ }^{48}$

Keadaan relaksasi ini telah dipraktikkan dan dijadikan teknik pengobatan pada masa lalu. Salah satu cara yang dianggap dapat membangkitkan respons relaksasi adalah duduk tafakur, atau yang dikenal orang saat ini sebagai meditasi. Cara lain mendapatkan respon relaksasi adalah berdoa dan latihan pernapasan.

Maka anak-anak yang membaca buku cerita dalam keadaan tenang atau

${ }^{45}$ Taufik Pasiak. (2002). Revolusi IQ/EQ/SQ Menyingkap Rahasia kecerdasan Berdasarkan Al Qur"an dan Nerurosains Mutakhir. Jakarta: Mizan, hlm. 226.

${ }^{46}$ Taufik Pasiak. (2002). Revolusi IQ/EQ/SQ Menyingkap Rahasia kecerdasan Berdasarkan Al Qur"an dan Nerurosains Mutakhir. Jakarta: Mizan, hlm. 219.

47 Taufik Pasiak. (2002). Revolusi IQ/EQ/SQ Menyingkap Rahasia kecerdasan Berdasarkan Al Qur"an dan Nerurosains Mutakhir. Jakarta: Mizan, hlm. 226.

${ }^{48}$ Taufik Pasiak. (2002). Revolusi IQ/EQ/SQ Menyingkap Rahasia kecerdasan Berdasarkan Al Qur"an dan Nerurosains Mutakhir. Jakarta: Mizan, hlm. 230. 
mendengarkan cerita dalam keadaan relaks dalam rekayasa lingkungan yang nyaman dengan suara musik yang menenangkan akan memicu munculnya gelombang alfa sehingga anak akan lebih mudah mengingat dan menceritakan kembali hal yang didengar dan dibacanya. Demikian pula halnya dengan anak-anak yang menonton film kartun dengan tekun akan lebih mampu mengikuti alur cerita bahkan sikap dan penokohan sitokoh dengan lebih baik.

\section{Faktor penghambat pengaruh cerita pada anak}

Beberapa hal yang dapat menghambat masuknya pengaruh cerita pada anak dan menyebabkan tujuan pengembangan kepribadian anak melalui cerita menjadi tidak efektif, adalah sebagai berikut:

a. Materi cerita bersifat formal sehingga seringkali cerita (kisah) yang disampaikan menjadi kering. ${ }^{49}$ Cerita yang kaku dan terlalu resmi serta tidak dikembangkan dengan baik melalui alur cerita dan penokohan yang menarik akan menjadi kering dan tidak menarik anak untuk mendengarkan atau membaca cerita tersebut.

b. Penyampaian materi cerita dilakukan secara doktrinal sehingga justru mematikan daya imajinasi anak. Dilakukannya doktrinasi terhadap anak oleh orang tua maupun gurunya melalui cerita yang itu-itu saja tanpa memberikan kesempatan pada anak untuk berimajinasi akan mematikan daya imajinasi anak sendiri. Anak dibebankan tugas menghafalnya

${ }^{49}$ Irawati Istadi. (2006). Mendidik dengan Cinta. Bekasi: Pustaka Inti, hlm. 114. sehingga kisah yang seharusnya dapat mengembangkan imajinasi justru merusak daya imajinasi mereka. Akibatnya keteladan tokoh-tokohnya terlupakan. Anak tidak mampu memahami substansi dan nilai yang dikandung di dalamnya. ${ }^{50}$

c. Asumsi masyarakat bahwa cerita tradisional yang ada dan diturunkan secara turun-temurun dari leluhur berupa cerita rakyat sudah tidak perlu dibicarakan dan dianggap kurang berguna. $^{51}$

d. Durasi tidak tepat. Untuk mendengarkan cerita, rentang waktu seorang bayi untuk memperhatikan cerita hanya tiga menit, sedang anak yang berusia lebih tinggi mampu memperhatikan hingga sepuluh menit. Maka jika cerita tersebut mempunyai bab yang panjang membutuhkan waktu lebih lama dari sepuluh menit, maka harus dicari titik ketegangan untuk berhenti sehingga anak akan penasaran untuk mendengar kelanjutan cerita tersebut. ${ }^{52}$ Berhenti setelah satu atau dua halaman tidak akan menstimulasi minat baca anak.

e. Waktunya tidak sesuai. Kondisi tegang, stress, pusing merupakan penyebab paling ekstrem yang membuat pikiran

\footnotetext{
${ }^{50}$ Irawati Istadi. (2006). Mendidik dengan Cinta. Bekasi: Pustaka Inti, hlm. 115.

${ }^{51}$ Zainal Abidin S., Aiyub, Amilah, Haris ST. Lubis dan Asrul Siregar. (1990). Pengaruh Cerita Rakyat Terhadap Kehidupan Masyarakat di Daerah Toba; Analisis Sosiologi. Medan: Lembaga Penelitian Universitas Sumatra Utara, hlm. 17.

${ }^{52}$ Jim Trelease. (2008). Read Aloud Handbook; Mencerdaskan Anak dengan Membacakan Cerita Sejak Dini. Jakarta: Hikmah, hlm. 101.
} 
berada dalam kondisi beta. ${ }^{53}$ Otak sedang menunjukkan gelombang beta. Saat anak sedang mengalami gelombang beta pada saat itu ia tidak dapat berpikir jernih, pikiran tidak fokus dan sulit berkonsentrasi. ${ }^{54}$

f. Gaya bahasa menjemukan dan tidak sesuai perkembangan anak. Menggunakan bahasa yang sederhana dan mudah dipahami saat membacakan cerita pada anak-anak usia dini akan lebih mudah diterima dari pada jika menggunakan bahasa yang canggih yang tidak mereka pahami. Sedangkan untuk anak yang usia lebih tinggi, menggunakan bahasa dengan kosa kata baru maka akan memicu mereka untuk bertanya dan menambah perbendaharaan kata mereka. Jim Trelease mengatakan agar menghindari kalimat deskriptif yang panjang sebelum imajinasi dan rentang perhatian si anak bisa menangani kalimat seperti itu. ${ }^{55}$

g. Tampilan tidak menarik (monoton) serta alur cerita tidak kreatif dan imajinatif. Untuk bayi memang diawali dengan ilustrasi hitam putih, namun beralih ke buku bergambar yang berwarna cerah untuk membangkitkan rasa ingin tahu dan indera visual anak. ${ }^{56}$ Namun semua

${ }^{53}$ Taufik Pasiak. (2002). Revolusi IQ/EQ/SQ Menyingkap Rahasia kecerdasan Berdasarkan Al Qur"an dan Nerurosains Mutakhir. Jakarta: Mizan, hlm. 220-221.

${ }^{54}$ Taufik Pasiak. (2002). Revolusi IQ/EQ/SQ Menyingkap Rahasia kecerdasan Berdasarkan Al Qur"an dan Nerurosains Mutakhir. Jakarta: Mizan, hlm. 220-221.

${ }^{55}$ Jim Trelease. (2008). Read Aloud Handbook; Mencerdaskan Anak dengan Membacakan Cerita Sejak Dini. Jakarta: Hikmah, hlm. 103.

${ }^{56}$ Jim Trelease. (2008). Read Aloud Handbook; Mencerdaskan Anak dengan Membacakan Cerita Sejak Dini. Jakarta: Hikmah, hlm. 100. orang suka buku bergambar yang bagus dan penuh warna, terutama anak-anak. Sedangkan alur cerita yang tidak kreatif dan tidak imajinatif akan membuat anak menjadi cepat bosan dan tidak mendengarkan cerita tersebut hingga selesai.

h. Materi tidak sesuai tahapan perkembangan usia. Ketika membacakan cerita jangan membuat anak yang mendengarkan kesulitan memahami cerita. Harus mempertimbangkan tingkat intelektual, sosial dan emosional pada tahapan perkembangan anak, 57 demikian dijelaskan Jim Trelease dalam Read Aloud Hand book Mencerdaskan Anak dengan Membacakan Cerita Sejak Dini. Namun ia juga menyarankan agar sesekali membacakan anak dengan materi di atas tingkat intelektual anak untuk menantang benak dan pikiran mereka.

Dari pembahasan di atas dapat dibuat rangkuman dan sebagainya mengenai faktor-faktor yang mendorong dan menghambat pengaruh materi cerita terhadap perkembangan kepribadian anak.

\section{E. PENUTUP}

Berdasarkan pembahasan pada babbab sebelumnya dapat disimpulkan hal-hal sebagai berikut:

1. Jenis cerita yang dipandang berpengaruh pada perkembangan kepribadian anak ternyata berbeda-beda untuk tiap tahapan usia.

\footnotetext{
${ }^{57}$ Jim Trelease. (2008). Read Aloud Handbook; Mencerdaskan Anak dengan Membacakan Cerita Sejak Dini. Jakarta: Hikmah, hlm. 105
} 
2. Faktor pendorong efektivitas cerita adalah judul yang menarik, disampaikan secara intensif, dilakukan pada waktu yang tepat saat anak dalam keadaan relaks dan tenang (saat gelombang alfa 7-8 sampai $13 \mathrm{~Hz}$ ), memakai gaya bahasa sederhana dengan alur cerita kreatif dan imajinatif sehingga dapat memacu daya kreatifitas anak dan imajinasi sangat penting. Serta materi cerita sesuai tahapan usia pendengar atau pembacanya dan memakai media yang tepat.

\section{DAFTAR PUSTAKA}

Asmawati. (2009). Dongeng Bunda Cerahkan Masa Depan Anak. Jakarta.

Ath-Thuri, H. A. (2007). Mendidik Anak Perempuan di Masa Kanak-Kanak. Jakarta: AMZAH.

Baharuddin. ( 2009). Pendidikan dan Psikologi Perkembangan. Jogjakarta: Ar-Ruzz Media.

Djaali. (2009). Psikologi Pendidikan. Jakarta: Bumi Aksara.

Egan, K. (2009). Pengajaran Yang Imajinatif (An Imaginative Approach to Teaching). Jakarta: Indeks.

Fajri, E. Z. (n.d.). Kamus Lengkap Bahasa Indonesia. Jakarta: Difa Publiser.

Hawari. (2011). Bukan Dongeng Tapi Kisah Sebelum Tidur. Jakarta:.
3. Faktor penghambat, yaitu bersifat formal, kaku, kering ide, disampaikan secara doktrinasi, durasi tidak tepat, disampaikan pada waktu yang tidak sesuai ketika anak dalam kondisi otak gelombang beta yang disebabkan oleh stress, frustasi, bingung dan pusing, memakai gaya bahasa menjemukan dengan alur cerita yang tidak kreatif dan imajinatif. Selain itu materi cerita diberikan tidak sesuai tahapan perkembangan tingkat intelektual, sosial dan emosional anak.

Huda, N. F. (2010). Kiat Membentuk Anak Berkarakter Hebat. Yogyakarta: Bidadari Biru.

Hurlock, E. B. (1993). Perkembangan Anak. Jakarta: Gelora Aksara Pratama.

Istadi, I. (2006). Mendidik dengan Cinta. Bekasi: Pustaka Inti.

Lebah, P. (2010). Around The World Amazing Stories of Great Sites Book Three America. Jakarta: Pustaka Lebah.

Mujib, A. (2006). Kepribadian dalam Psikologi Islam. Jakarta: Raja Grafindo Persada.

Noor, R. M. (2011). Pendidikan Karakter Berbasis Sastra, Solusi Pendidikan Moral yang Efektif. Jogjakarta: Ar Ruzz Media.

Nur'ani, F. (2010). Membentuk Karakter Anak dengan Dongeng. Surakarta: Indiparent. 
Pasiak, T. (2002). Revolusi IQ/EQ/SQ Menyingkap Rahasia kecerdasan Berdasarkan Al Qur"an dan Nerurosains Mutakhir. Jakarta: Mizan.

Putra, S. (2009). Anakku Bertingkah Seperti Sponge Bob, Siasat Mendampingi Anak Anda dalam Menonton Film Kartun. Jakarta: Pustaka Widyamara.

Risnawati, E. d. ( 2013). Telaah Materi Dongeng pada Mata Pelajaran Bahasa Sunda Sekolah Dasar (Analisis Kurikulum Bahasa Sunda Sekolah Dasar Berbasis Tauhid). Jurnal Sosial Humaniora, 4 (2).

Ronnberg, M. (2002). Why is Disney So Popular? The Animated Feature Films From a Childish Perspective. Sweden: Filmforlaget, Uppsala.

Simandjuntak, P. d. (1984). Teori Kepribadian. Bandung: Tarsito.
Trelease, J. (2008). Read Aloud Handbook; Mencerdaskan Anak dengan Membacakan Cerita Sejak Dini. Jakarta: Hikmah.

Ulwan, A. N. (2007). Pendidikan Anak dalam Islam. Jakarta: Pustaka Amani.

Abidin S. Zainal, Aiyub, Amilah, Lubis, Haris ST. dan Siregar, Asrul. 1990. Pengaruh Cerita Rakyat Terhadap Kehidupan Masyarakat di Daerah Toba; Analisis Sosiologi. Medan: Lembaga Penelitian Universitas Sumatra Utara.

Risnawati, E. dan Mujahidin, Endin. (2013). Telaah Materi Dongeng pada Mata Pelajaran Bahasa Sunda Sekolah Dasar (Analisis Kurikulum Bahasa Sunda Sekolah Dasar Berbasis Tauhid). Jurnal Sosial Humaniora. 4 (2). 